\title{
Personalized Medicine: Foreword
}

\author{
Adam Tarring ${ }^{* 1}$ \\ ${ }^{1}$ Future Science Group, Unitec House, 2 Albert Place, London N31QB, UK \\ * Author for correspondence: a.tarring@futuremedicine.com
}

"The key focus areas included policy, ethics and the clinical applications of PME; we would expect these areas and many more to be focuses in the coming year."

Welcome to Volume 15 of Personalized Medicine (PME). In this Foreword, we will present some of the highlights of the last 12 months as well as discuss what we are looking forward to in the year ahead.

We would also like to take this opportunity to thank our readers, reviewers, authors and editorial board members for their support in the last year and look forward to working with everyone as we move into the New Year.

\section{Content highlights of 2017}

2017 was another great year for the journal, with a number of high quality submissions and articles looking better than ever on our new website [1]. The top ten most read articles of the past year are shown in Table 1; these articles show the diverse research that is being done in the field as well as some of the key focus areas. The key focus areas included policy, ethics and the clinical applications of PME; we would expect these areas and many more to be focuses in the coming year.

\section{Readership demographics}

The readership of the journal is shown in Figure 1, with the majority of readers coming from North America (47\%) and Europe (32\%). While our content is reaching scientific communities that are more established in PME, we would hope to see growth in our readership in emerging scientific communities as PME becomes more established.

\section{Social media}

PME is active on Twitter at @fsgpme [12], where we have continued to post about the latest news and newly published articles from the journal.

\section{Editorial board}

We have seen a change in the editorial board structure this year, with Geoffrey Ginsburg (Duke University, USA) being promoted to senior editor.

\section{Conclusion}

We appreciate any feedback on the direction of the journal, especially any priority topics that deserve recognition in the journal. We welcome unsolicited research, review and opinion article proposals and would be delighted to hear from you if you are interested in submitting to the journal. For submitting authors, PME offers various services to increase the speed and reach of their articles, including our accelerated publication and open access options. Interested readers can find out more on our website [13].

Many thanks for your continuing interest and support of PME; we look forward to working with many of you over the coming year. 


\begin{tabular}{|c|c|c|c|c|}
\hline Rank & Title & Author(s) & Volume (issue) & Ref. \\
\hline 1 & $\begin{array}{l}\text { Strategies for integrating personalized medicine into healthcare } \\
\text { practice }\end{array}$ & $\begin{array}{l}\text { Pritchard DE, Moeckel F, Villa } \\
\text { MS et al. }\end{array}$ & $14(2)$ & [2] \\
\hline 2 & $\begin{array}{l}\text { Direct-to-consumer genetic testing: where and how does genetic } \\
\text { counseling fit? }\end{array}$ & $\begin{array}{l}\text { Middleton A, Mendes A, } \\
\text { Benjamin CM \& Howard HC }\end{array}$ & 14(3) & [3] \\
\hline 3 & $\begin{array}{l}\text { Clinical application of a cancer genomic profiling assay to guide } \\
\text { precision medicine decisions }\end{array}$ & Eifert C, Pantazi A, Sun R et al. & $14(4)$ & [4] \\
\hline 4 & $\begin{array}{l}\text { The fuzzy world of precision medicine: deliberations of a precision } \\
\text { medicine tumor board }\end{array}$ & $\begin{array}{l}\text { McGraw SA, Garber J, Jänne } \\
\text { PA et al. }\end{array}$ & 14(1) & [5] \\
\hline 5 & Update: looking beyond the 100,000 Genome Project & Haga SB & $14(2)$ & [6] \\
\hline 6 & $\begin{array}{l}\text { Primary care physician experiences with integrated } \\
\text { pharmacogenomic testing in a community health system }\end{array}$ & $\begin{array}{l}\text { Lemke } A \text {, Selkirk CG, Glaser } \\
\mathrm{N} \text { et al. }\end{array}$ & $14(5)$ & [7] \\
\hline 7 & $\begin{array}{l}\text { The next personalized medicine evolution in orthopedics: how } \\
\text { diagnosing and treating scoliosis are about to change }\end{array}$ & Moreau A & $14(2)$ & [8] \\
\hline 8 & $\begin{array}{l}\text { Enabling personalized medicine in Europe by the European } \\
\text { Commission's funding activities }\end{array}$ & $\begin{array}{l}\text { Nimmesgern E, Norstedt I \& } \\
\text { Draghia-Akli R }\end{array}$ & $14(4)$ & [9] \\
\hline 9 & $\begin{array}{l}\text { The influence of a gene-expression signature on the treatment of } \\
\text { diagnostically challenging melanocytic lesions }\end{array}$ & $\begin{array}{l}\text { Cockerell C, Tschen J, Billings } \\
\text { SD et al. }\end{array}$ & $14(2)$ & [10] \\
\hline 10 & Psychiatry is warming up to personalized medicine 2.0 & Blom JD & 14(3) & [11] \\
\hline
\end{tabular}

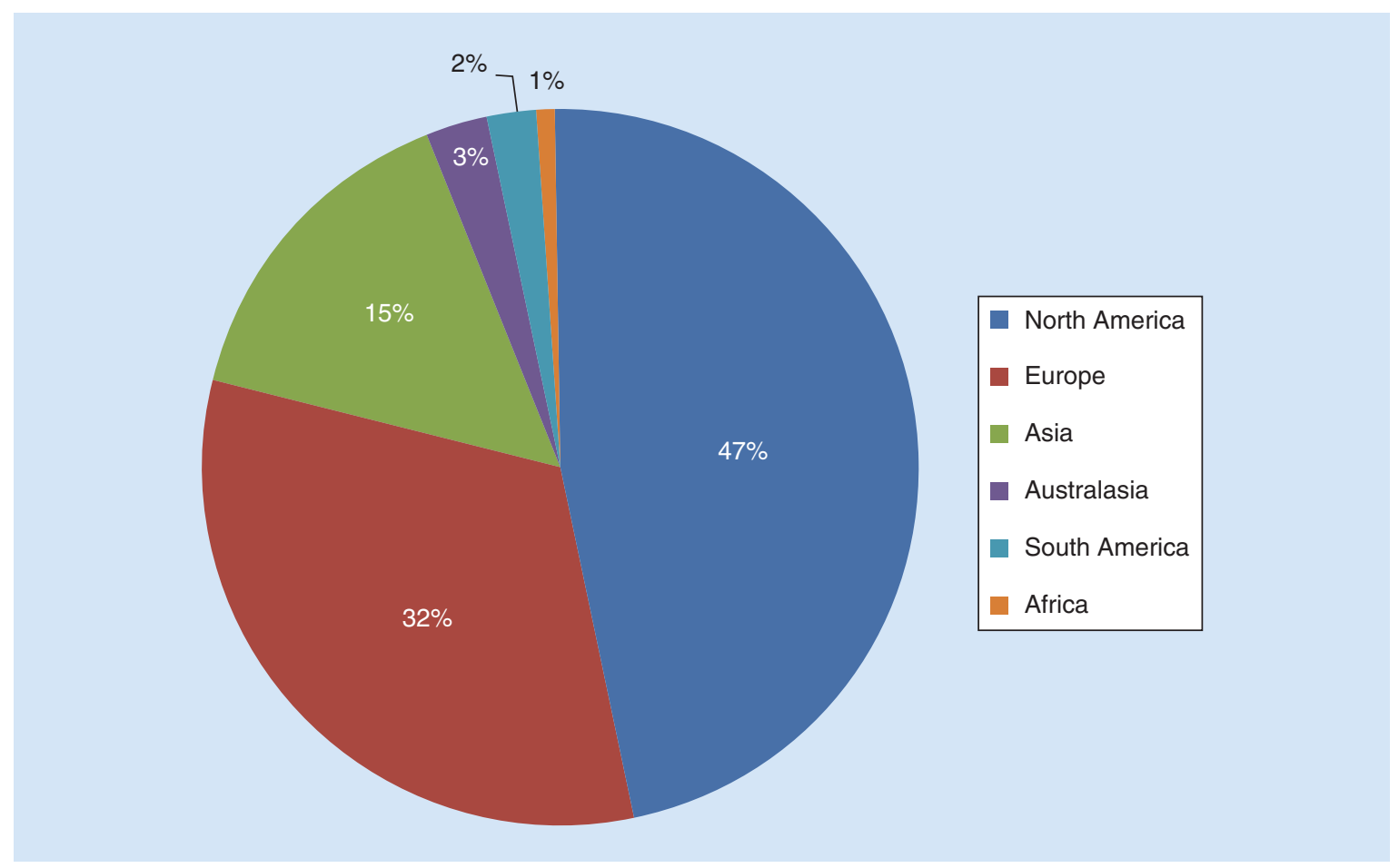

Figure 1. Personalized Medicine reader demographics 2017. 
Financial \& competing interests disclosure

A Tarring is an employee of Future Medicine Ltd, publisher of Personalized Medicine. The author has no other relevant affiliations or financial involvement with any organization or entity with a financial interest in or financial conflict with the subject matter or materials discussed in the manuscript apart from those disclosed.

No writing assistance was utilized in the production of this manuscript.

\section{References}

1 Personalized Medicine website: www.futuremedicine.com/journal/pme?journalCode=pme

2 Pritchard DE, Moeckel F, Villa MS et al. Strategies for integrating personalized medicine into healthcare practice. Per. Med. 14(2), 141-152 (2017).

3 Middleton A, Mendes A, Benjamin CM, Howard HC. Direct-to-consumer genetic testing: where and how does genetic counseling fit? Per. Med. 14(3), 249-257 (2017).

4 Eifert C, Pantazi A, Sun R et al. Clinical application of a cancer genomic profiling assay to guide precision medicine decisions. Per. Med. 14(4), 309-325 (2017).

5 McGraw SA, Garber J, Jänne PA et al. The fuzzy world of precision medicine: deliberations of a precision medicine tumor board. Per. Med. 14(1), 37-50 (2017).

6 Haga SB. Update: looking beyond the 100,000 Genome Project. Per. Med. 14(2), 85-87 (2017).

7 Lemke A, Selkirk CG, Glaser N et al. Primary care physician experiences with integrated pharmacogenomic testing in a community health system. Per. Med. 14(5), 389-400 (2017).

8 Moreau A. The next personalized medicine evolution in orthopedics: how diagnosing and treating scoliosis are about to change. Per. Med. 14(2), 89-92 (2017).

9 Nimmesgern E, Norstedt I, Draghia-Akli R. Enabling personalized medicine in Europe by the European Commission's funding activities. Per. Med. 14(4), 355-365 (2017).

10 Cockerell C, Tschen J, Billings SD et al. The influence of a gene-expression signature on the treatment of diagnostically challenging melanocytic lesions. Per. Med. 14(2), 123-130 (2017).

11 Blom JD. Psychiatry is warming up to personalized medicine 2.0. Per. Med. 14(3), 185-187 (2017).

12 Twitter: Personalized Medicine: https://twitter.com/fsgpme

13 Future Science Group Publishing Solutions: www.future-science-group.com/services/for-professionals/publication-solutions/ 